\title{
Synergistic Effect of Heating pH and Transglutaminase on the Gelation Kinetics and Texture of Yak Skim Milk Gels
}

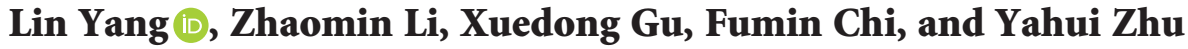 \\ College of Food Science, Tibet Agriculture and Animal Husbandry University, Nyingchi 860000, China \\ Correspondence should be addressed to Lin Yang; yanglintibet@sina.com
}

Received 31 October 2020; Revised 15 February 2021; Accepted 27 February 2021; Published 8 March 2021

Academic Editor: Qing-Jie Sun

Copyright (c) 2021 Lin Yang et al. This is an open access article distributed under the Creative Commons Attribution License, which permits unrestricted use, distribution, and reproduction in any medium, provided the original work is properly cited.

\begin{abstract}
Textural defects (including syneresis and poor consistency) often occur in yogurt gels produced from yak milk. In this research, the synergistic effects of transglutaminase (TGase) and heating $\mathrm{pH}$ on the textural properties of acidified yak skim milk gels, as well as the related mechanism of action, were investigated. The $\mathrm{pH}$ values of yak skim milk were adjusted to 6.3, 6.7, and 7.1, respectively. The samples were heated at $80^{\circ} \mathrm{C}$ for $30 \mathrm{~min}$ and then cooled to $42^{\circ} \mathrm{C}$. After treatment with different contents of TGase $(0,3$, and $10 \mathrm{U}$ TGase per gram proteins), the samples were acidified with glucono-delta-lactone. For a given TGase content, the final storage modulus $\left(G^{\prime}\right)$ of gels was positively related to the heating $\mathrm{pH}$, whereas the opposite trend was observed for the gelation time. This effect was obvious between $\mathrm{pH} 6.3$ and 6.7. At a definite heating $\mathrm{pH}$ value, the final $\mathrm{G}^{\prime}$ of the gels was highest at $3 \mathrm{U}$ TGase per gram proteins. The highest water holding capacity and firmness value were observed in gels prepared using pH 7.1 and $3 \mathrm{U}$ TGase per gram proteins. In the samples treated with $3 \mathrm{U}$ TGase per gram proteins (preheating $\mathrm{pH}$ 7.1), more rigid network structures were seen in the gel than 0 or $10 \mathrm{U}$ TGase per gram proteins. Therefore, adjusting the heating $\mathrm{pH}$ values and TGase contents is an effective way of improving the textural properties of yak milk gels.
\end{abstract}

\section{Introduction}

The yak (Bos grunniens) is a unique animal in the QinghaiTibet Plateau area which has an altitude of over $3000 \mathrm{~m}$ in western China $[1,2]$. Yak milk-based products have received considerable attention worldwide. Compared with cow milk, yak milk is richer in nutrients, easier to digest, and has lower allergenicity [2-4]. Set-type yogurt produced from yak milk has become one of the most popular dairy products in western China due to its unique sensory and flavor characteristics [5]. However, during storage and long-distance transport, textural defects often occur in set-type yogurt produced from yak milk. These defects can be reflected in the syneresis and poor consistency of yogurt, which greatly reduce its acceptability. Therefore, it is important to improve the quality of set-type yogurt produced from yak milk.

The syneresis and consistency of set-type yogurt gels are closely related to the structural characteristics of gel networks [6-8]. The building blocks of the yogurt gel networks are milk proteins, including whey proteins and caseins [9]. In native milk, the phosphorylated serines in caseins are crosslinked by calcium phosphate, forming colloidal particles of approximately $200 \mathrm{~nm}$ in diameter [10, 11]. These colloids are named casein micelles. During acidification, caseins in the micelles are gradually liberated and then are rearranged into a weak network structure through noncovalent bonds at $\mathrm{pH} 4.6[12,13]$. To better improve the structural characteristics of gel networks, the introduction of covalent bonds into the yogurt gel network has been proved to be useful [14]. At present, two methods have been adapted to introduce covalent bonds: heat and transglutaminase (TGase) treatment of milk proteins.

Heat treatment before acidification has a significant impact on the gel properties $[15,16]$. After heat treatment, denaturation of whey proteins occurs $[17,18]$. It has been shown that by adjusting the $\mathrm{pH}$ of the milk before heat treatment, different amounts of denatured whey proteins are associated with the casein micelles [19]. When the milk pH before heating is lower than 6.7, most of the denatured whey proteins can interact with casein micelles. In this case, the denatured whey proteins are mainly in the micellar phase [20]. However, when the milk $\mathrm{pH}$ before heating is higher 
than 6.7, most of the denatured whey proteins interact covalently with the serum phase $\kappa$-casein. In this case, most of the denatured whey proteins exist in the soluble phase. It has been shown that both the final storage modulus $\left(G^{\prime}\right)$ and loss modulus $\left(\mathrm{G}^{\prime \prime}\right)$ are positively related to preheating $\mathrm{pH}$ in the range 6.2-6.9 [21]. TGase has been extensively used to produce covalent bonds among proteins. TGase catalyzes crosslinks between $\gamma$-carboxyl groups and $\varepsilon$-amino groups in different protein molecules. Following treatment with TGase, the syneresis and poor consistency of yogurt can be greatly improved [22].

Heat treatment and TGase might have a synergistic effect on acid gels. Native whey proteins are difficult to catalyze by TGase due to their folding structure. After heat treatment, the whey proteins are denatured and become unfolded. This results in the complete unfolding of all amino acid residues, which might easily be crosslinked by TGase treatment. Numerous studies have been carried out on the use of TGase and heat treatment on the gelation kinetics and texture of acid milk gels. However, few studies have been carried out on the effect of TGase and heating $\mathrm{pH}$ of yak skim milk in terms of the gelation kinetics and texture of acid-induced milk gels.

In the present study, in order to improve the syneresis and poor consistency of acidified yak milk gels, we investigated the effects of TGase and heating $\mathrm{pH}$ of yak skim milk on the gelation kinetics and texture of acid-induced milk gels.

\section{Materials and Methods}

2.1. Materials. Yak milk was collected from Pali grassland in northwest China. The altitude in this area is $4300 \mathrm{~m}$. The milk contained $0.85 \%(\mathrm{w} / \mathrm{v})$ ash, $18.42 \%$ dry matter, $5.91 \%$ protein, $7.22 \%$ fat, and $5.04 \%$ lactose, respectively. To inhibit the activity of plasmin and microbial growth, $0.03 \%$ trypsin inhibitor and $0.03 \%$ sodium azide were added to the samples [23]. The trypsin inhibitor, sodium azide, and glucono-deltalactone (GDL) were purchased from Sigma Aldrich (St. Louis, USA). TGase was purchased from Kelong Biotechnology Co., Ltd. (Jiangmen, Guangdong). The enzyme activity was $200 \mathrm{U} / \mathrm{g}$. The rennet Stamix 1150 was purchased from Chr. Hansen (Beijing, China).

2.2. Sample Preparation and Characterization. The experimental design in this study is shown in Figure 1. The sample treatment procedures and characterization methods are present in the following sections.

2.2.1. Preparation and Characterization of Heat-Treated Yak Skim Milk. Yak milk was defatted by centrifugation (5-5N, Hunan Hengnuo Instrument Equipment Co., Ltd., Changsha, China) at $5000 \mathrm{~g}$ for $20 \mathrm{~min}$ at $25^{\circ} \mathrm{C}$, followed by adjustment of the $\mathrm{pH}$ to $6.3,6.7$, or 7.1 with $2 \mathrm{~mol} / \mathrm{L} \mathrm{HCl}$ or $\mathrm{NaOH}$. The samples were heated at $80^{\circ} \mathrm{C}$ for $30 \mathrm{~min}$ and then cooled to $42^{\circ} \mathrm{C}$ in a waterbath. The rennet and acid precipitation method in combination with reversed phase high performance liquid chromatography (RP-HPLC) was used to evaluate the distribution of whey proteins, as reported previously $[19,24]$. In this method, the heat-treated samples were first acidified with $2 \mathrm{~mol} / \mathrm{L} \mathrm{HCl}$. Thirty minutes later, the dispersion was centrifuged at $5000 \mathrm{~g}$ for $30 \mathrm{~min}$ at $25^{\circ} \mathrm{C}$. The concentration of $\beta$-lactoglobulin in the supernatant was analyzed by RP-HPLC (Agilent 1100 Series, CA, USA) with a C4 column $(4.6 \times 250 \mathrm{~mm}, 300 \AA$, Phenomenex, CA, USA). Before the RP-HPLC determination, $0.3 \mathrm{~mL}$ of the supernatants was first added to $2.5 \mathrm{~mL}$ of reducing agents. The reducing agents contained $0.1 \mathrm{~mol} / \mathrm{L}$ Tris, $6 \mathrm{~mol} / \mathrm{L}$ urea, and $\beta$-mercaptoethanol $(0.4 \%, \mathrm{w} / \mathrm{v})$, followed by adjusted to $\mathrm{pH}$ 7.0 with $2 \mathrm{~mol} / \mathrm{L} \mathrm{HCl}$. Renneting of the heat-treated milk samples was carried out based on the reported literature [25]. Following the addition of rennet for $30 \mathrm{~min}$, the mixture was centrifuged at $5000 \mathrm{~g}$ for $30 \mathrm{~min}$ at $25^{\circ} \mathrm{C}$. The concentration of $\beta$-lactoglobulin in the supernatant was analyzed by RP-HPLC. Before the RP-HPLC determination, $0.3 \mathrm{~mL}$ of the supernatants was first added to $2.5 \mathrm{~mL}$ of reducing agents. Solvent A was distilled water (with $0.1 \%$ (v/ v) trifluoroacetic acid); solvent B was acetonitrile (with $0.1 \%$ trifluoroacetic acid). A linear gradient from $35.0 \%$ to $55.0 \%$ of solvent B over 60 min was used.

Yak milk $(300 \mu \mathrm{L}$ was added to $2.7 \mathrm{~mL}$ of reducing agent solution (including $0.1 \mathrm{~mol} / \mathrm{L}$ Tris, $6 \mathrm{~mol} / \mathrm{L}$ urea, $\beta$-mercaptoethanol $(0.4 \%, \mathrm{w} / \mathrm{v})$, adjusted to $\mathrm{pH} 7.0$ with $2 \mathrm{~mol} / \mathrm{L}$ $\mathrm{HCl}$ ). Solvent A was distilled water (with $0.1 \%(\mathrm{v} / \mathrm{v})$ trifluoroacetic acid); solvent B was acetonitrile (with $0.1 \%$ trifluoroacetic acid). A linear gradient from $35.0 \%$ to $55.0 \%$ of solvent B over 60 min was used.

\subsubsection{Preparation and Characterization of TGase-Treated} Samples. After heat treatment, TGase was added to the samples of 0,3 , and $8 \mathrm{U} / \mathrm{g}$ milk proteins. The samples were magnetically stirred for $5 \mathrm{~min}$ and incubated at $42^{\circ} \mathrm{C}$ in a waterbath for $40 \mathrm{~min}$. The TGase in the samples was inactivated at $75^{\circ} \mathrm{C}$ for $10 \mathrm{~min}$. The $\mathrm{pH}$ values in the samples were readjusted to 6.7 before GDL addition, with $2 \mathrm{~mol} / \mathrm{L} \mathrm{HCl}$ or $\mathrm{NaOH}$.

The degree of covalent crosslinking in the heat- and TGase-treated samples was measured by a spectrometer, as reported previously [26]. Briefly, $10 \mathrm{~mL}$ of the heat- and TGase-treated samples were freeze-dried (FD-1A-50, Hangzhou Chuanyi Experimental Instrument Co. Ltd., Hangzhou, China) to constant weight for $48 \mathrm{~h}$. One milliliter of $4 \% \mathrm{NaHCO}_{3}$ solution and $1 \mathrm{~mL}$ of $0.2 \%(\mathrm{w} / \mathrm{v})$ trinitrobenzene-sulfonic acid solution were added to $10 \mathrm{mg}$ dried samples. After incubation at $42^{\circ} \mathrm{C}$ for $4 \mathrm{~h}$, the samples were digested with $3 \mathrm{~mL} 6 \mathrm{~mol} / \mathrm{L}$ at $65^{\circ} \mathrm{C}$ for $2 \mathrm{~h}$. Following dilution with distilled water to $15 \mathrm{~mL}$, the samples were added to cuvettes for absorbance determination (U-2900 spectrometer, Hitachi, Ltd., Tokyo, Japan). The crosslinking degree (DE) was calculated as follows:

$$
\mathrm{DE}(\%)=\left(1-\frac{A_{\mathrm{S}} / m_{\mathrm{s}}}{A_{\mathrm{NS}} / m_{\mathrm{Ns}}}\right) \times 100 \%,
$$

where $A_{\mathrm{S}}$ and $A_{\mathrm{NS}}$ is the absorbance of TGase-treated and nonTGase-treated samples, respectively. $m_{\mathrm{s}}$ and $m_{\mathrm{Ns}}$ is the mass of TGase-treated and non-TGase-treated samples, respectively. 


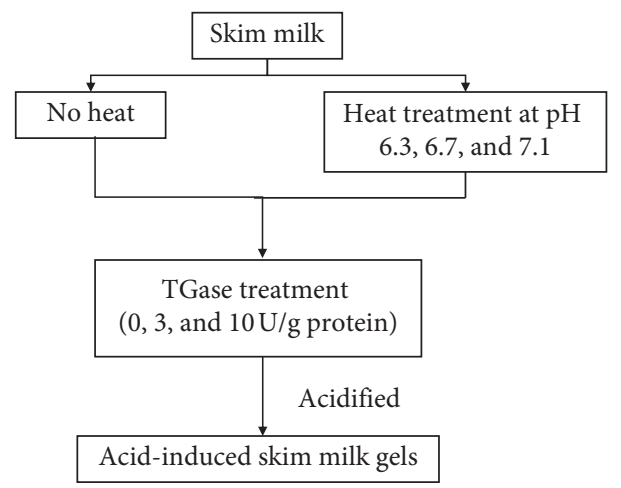

Figure 1: The experimental design of the study.

2.2.3. Preparation and Characterization of Acidified Milk Gels. The yak skim milk was acidified with $1.35 \%$ GDL at $37^{\circ} \mathrm{C}$ for $6 \mathrm{~h}$. The final $\mathrm{pH}$ value of all the acidified skim milk gels was 4.4. The samples were stored at $4^{\circ} \mathrm{C}$ before use. The gelation kinetics of the samples were determined using a rheometer (AR 2000, TA Instruments, USA), equipped with a concentric cylinder. GDL was directly added to the TGasetreated samples to $1.35 \%$. The samples were then added to the concentric cylinder after the addition of GDL for $2 \mathrm{~min}$ and were oscillated at $0.1 \mathrm{~Hz}$ and $37^{\circ} \mathrm{C}$ with a strain of $1 \%$. Gelation time was defined as the point when $\mathrm{G}^{\prime}$ of the samples was more than $1 \mathrm{~Pa}$.

The firmness of the gels was measured by a texture analyzer (TMS-Pro, Sterling, USA). The gels were stored at $25^{\circ} \mathrm{C}$ for 120 min before texture measurement. A probe (with a diameter of $25 \mathrm{~mm}$ ) was vertically moved into the samples to $15 \mathrm{~mm}$ at $25 \mathrm{~mm} / \mathrm{min}$ for penetration measurement.

The water holding capacity (WHC) of the acidified milk gels was measured according to a modified method [24]. Eight millimeters of the TGase-treated samples were acidified for $4 \mathrm{~h}$ at $37^{\circ} \mathrm{C}$ in $10 \mathrm{~mL}$ tubes. After acidification, the samples were centrifuged at $800 \mathrm{~g}$ at $25^{\circ} \mathrm{C}$ for $10 \mathrm{~min}$. The WHC was calculated as the percentage of the gel weight at the bottom of the centrifuge tubes compared to the initial weight.

The structural characteristics of the gels were determined by cryoscanning electron microscopy (S-3000N, Hitachi Co., Tokyo, Japan). Samples were added into the specimen holder and sublimated at $-90^{\circ} \mathrm{C}$ for $25 \mathrm{~min}$ before observation (Quorum PP 3000T, UK).

2.3. Statistical Analysis. Independent experiments were repeated three times. Analysis of variance (ANOVA) was used to determine significant differences $(P<0.05)$. Statistical analyses were carried out using IBM SPSS 21 for Windows 10.0. Duncan's multiple range tests for differences were performed.

\section{Results and Discussion}

3.1. Extent of Denaturation of Whey Proteins and Their Distribution. The distribution of whey proteins can be evaluated with the rennet and acid precipitation method. This is because the casein micelles can be precipitated in the presence of rennet, while both casein micelles and denatured whey proteins can be precipitated at $\mathrm{pH}$ 4.6. The distribution of whey proteins including native whey proteins, whey protein aggregates in the soluble phase, and whey proteins associated with the casein micelles were determined, respectively. Table 1 gives the distribution of the highest content of whey protein in yak milk, $\beta$-lactoglobulin [27], after different heat treatments. No statistical differences were observed in the degree of undenatured $\beta$-lactoglobulin. This indicated that the degree of denaturation was little influenced by the heating $\mathrm{pH}$ of yak skim milk. However, the degree of denatured $\beta$-lactoglobulin present in the soluble or micellar phase was closely related to the heating $\mathrm{pH}$ of yak skim milk. When heated at $\mathrm{pH} 6.3$, only $18.5 \%$ of $\beta$-lactoglobulin was present in the soluble phase; this value increased to $48.2 \%$ when the heating $\mathrm{pH}$ was 7.1 .

3.2. Gelation Kinetics. The evolution of the storage modulus $\left(G^{\prime}\right)$ after the addition of GDL to skim milk samples treated with different preheating $\mathrm{pH}$ values and TGase contents is presented in Figure 2. $\mathrm{G}^{\prime}$ and gelation time are summarized in Table 2. Preheating $\mathrm{pH}$ had a significant impact on the final $G^{\prime}$ and gelation time (except for the case for $0 \mathrm{U} / \mathrm{g}$ protein). For a given TGase content, the final $\mathrm{G}^{\prime}$ was positively related to the preheating $\mathrm{pH}$ as the preheating $\mathrm{pH}$ increased from 6.3 to 7.1, whereas the opposite trend was observed for the gelation time. This effect was obvious between $\mathrm{pH} 6.3$ and 6.7 but was smaller between preheating $\mathrm{pH}$ 6.7 and 7.1. These results are generally consistent with previously reported results [26].

It was observed at a definite preheating $\mathrm{pH}$ value that the TGase content had a significant impact on the final $G^{\prime}$ and gelation time. Surprisingly, when the preheating $\mathrm{pH}$ was 6.7, the maximum $G^{\prime}$ value was observed in the sample treated with $3 \mathrm{U}$ TGase per gram proteins, followed by $10 \mathrm{U}$ TGase per gram proteins. Similar results were also observed when the preheating $\mathrm{pH}$ was 6.3 or 7.1. In summary, at a definite $\mathrm{pH}$ value, the maximum $\mathrm{G}^{\prime}$ value was observed in the $3 \mathrm{U}$ TGase per gram proteins sample, whereas the opposite trend was found for the gelation time. During acidification, caseins in the micelles are gradually liberated and rearranged into a weak network structure through noncovalent bonds at $\mathrm{pH}$ 4.6. Although the introduction of covalent bonds is a useful 
TABLE 1: The denaturation extent of $\beta$-lactoglobulin and its distribution.

\begin{tabular}{lccc}
\hline Heating pH & Native (\%) & Soluble phase (\%) & Micellar phase (\%) \\
\hline pH 7.1 & $7.3 \pm 1.8^{\mathrm{a}}$ & $48.2 \pm 3.7^{\mathrm{c}}$ & $45.0 \pm 5.1^{\mathrm{a}}$ \\
pH 6.7 & $8.2 \pm 1.6^{\mathrm{a}}$ & $33.2 \pm 4.0^{\mathrm{b}}$ & $56.8 \pm 7.6^{\mathrm{b}}$ \\
pH 6.3 & $7.1 \pm 0.6^{\mathrm{a}}$ & $18.5 \pm 4.2^{\mathrm{a}}$ & $76.2 \pm 5.9^{\mathrm{c}}$ \\
\hline
\end{tabular}

Native, soluble phase, and micellar phase are represented by native whey proteins, whey protein aggregates in the soluble phase, and whey proteins associated with casein micelles, respectively. Values are mean \pm standard deviation; means with different superscript letters within the same column are significantly different $(P<0.05)$

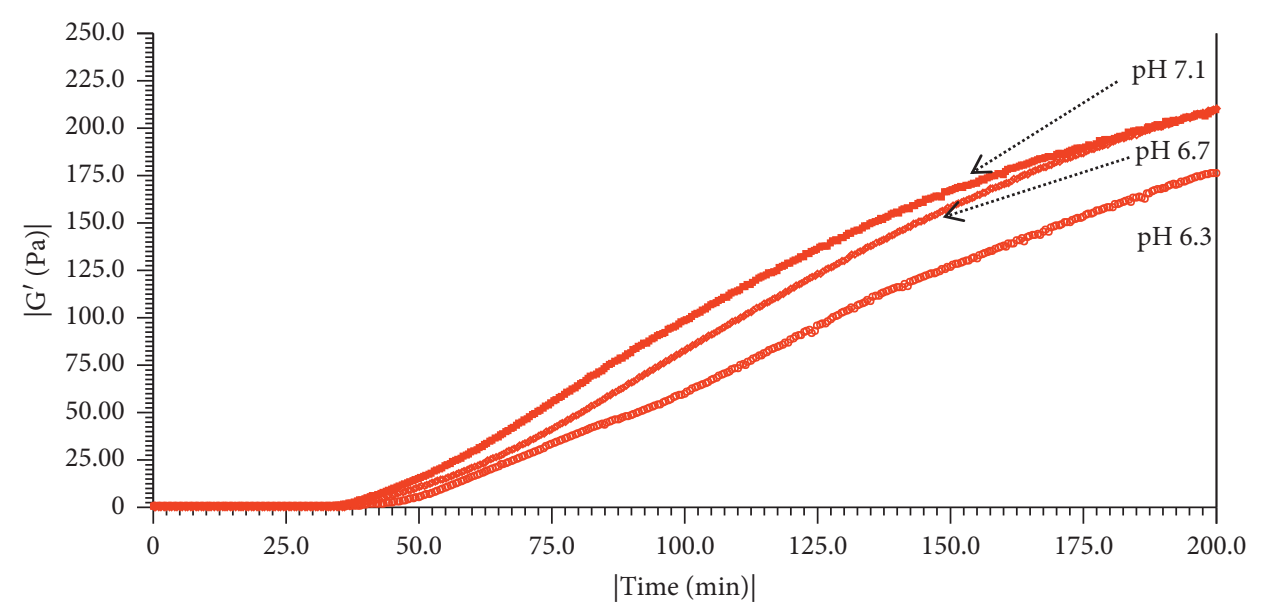

(a)

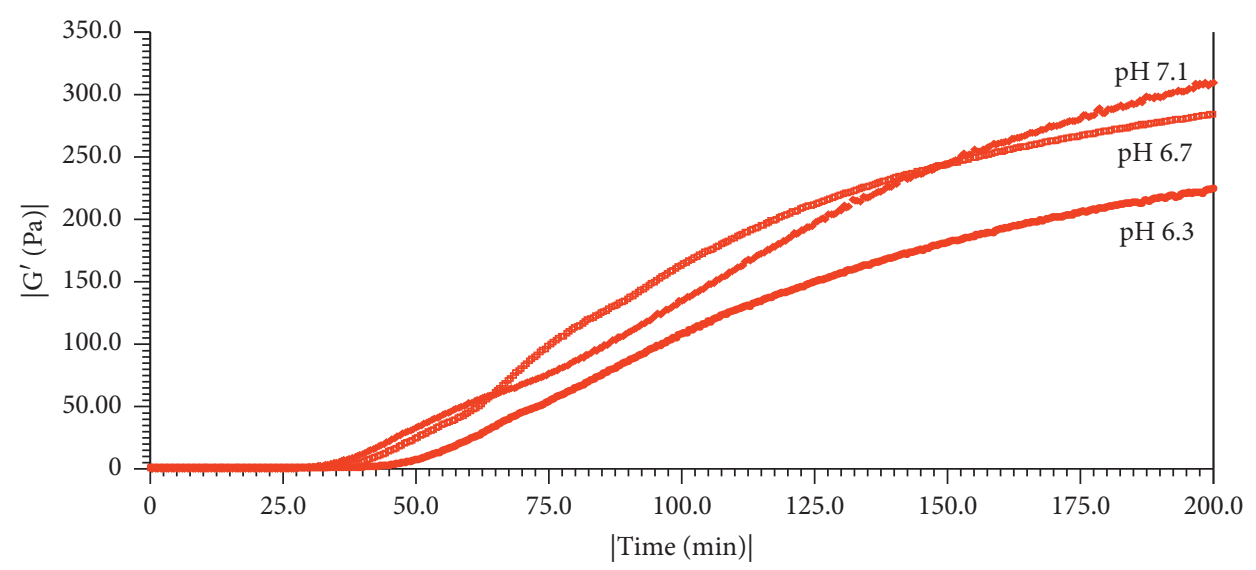

(b)

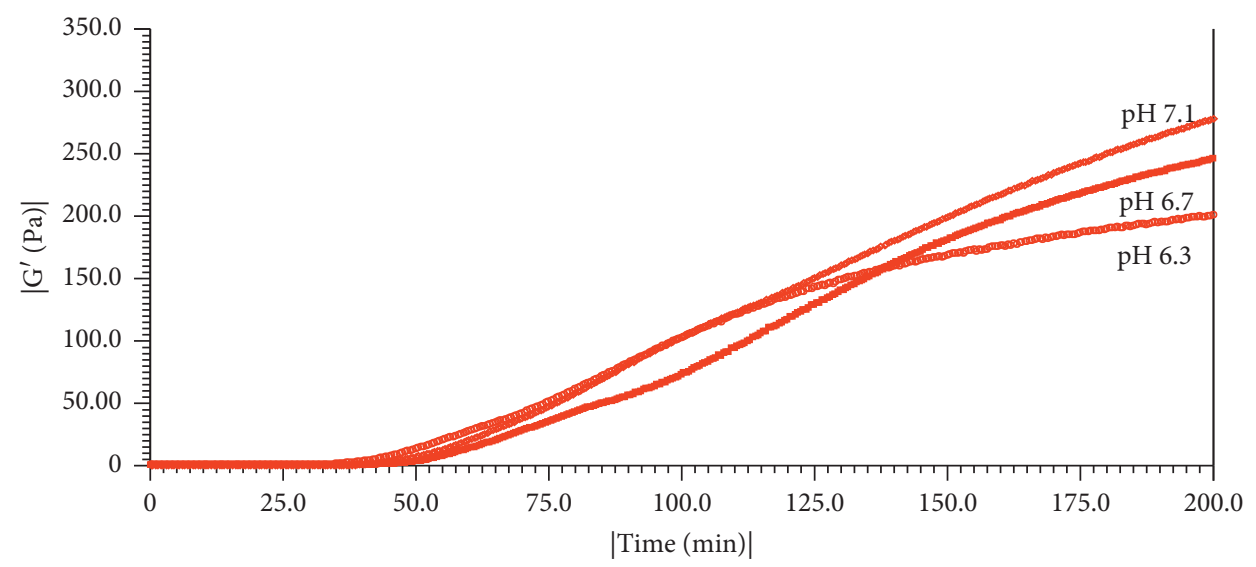

(c)

Figure 2: Effect of transglutaminase and preheating $\mathrm{pH}$ on the storage modulus of acid-induced gels prepared from 0 (a), 3 (b), and 10 (c) U transglutaminase per gram proteins. 
TABLE 2: Effect of preheating $\mathrm{pH}$ and TGase contents on the $\mathrm{G}^{\prime}$ and gelation time of acid-induced yak milk gels.

\begin{tabular}{|c|c|c|c|c|c|c|}
\hline & \multicolumn{3}{|c|}{$\mathrm{G}^{\prime}(\mathrm{Pa})$} & \multicolumn{3}{|c|}{ Gelation (min) } \\
\hline & $0 \mathrm{U} / \mathrm{g}$ protein & $3 \mathrm{U} / \mathrm{g}$ protein & $10 \mathrm{U} / \mathrm{g}$ protein & $0 \mathrm{U} / \mathrm{g}$ protein & $3 \mathrm{U} / \mathrm{g}$ protein & $10 \mathrm{U} / \mathrm{g}$ protein \\
\hline Heating pH 7.1 & $221.3 \pm 18.2^{\mathrm{a}}$ & $320.5 \pm 15.1^{\mathrm{c}}$ & $275.7 \pm 16.4^{\mathrm{b}}$ & $36.5 \pm 2.5^{\mathrm{a}}$ & $27.5 \pm 3.2^{\mathrm{a}}$ & $39.5 \pm 2.2^{\mathrm{ab}}$ \\
\hline Heating $\mathrm{pH} 6.7$ & $217.9 \pm 22.4^{\mathrm{a}}$ & $281.6 \pm 22.0^{\mathrm{b}}$ & $259.4 \pm 20.1^{\mathrm{b}}$ & $37.5 \pm 1.8^{\mathrm{a}}$ & $34.9 \pm 2.8^{\mathrm{b}}$ & $42.5 \pm 4.0^{\mathrm{b}}$ \\
\hline Heating pH 6.3 & $188.1 \pm 17.0^{\mathrm{a}}$ & $230.2 \pm 14.6^{\mathrm{a}}$ & $206.9 \pm 18.5^{\mathrm{a}}$ & $41.2 \pm 3.7^{\mathrm{b}}$ & $42.7 \pm 1.4^{\mathrm{c}}$ & $36.2 \pm 2.8^{\mathrm{a}}$ \\
\hline
\end{tabular}

Values are mean \pm standard deviation; means with different superscript letters within the same column are significantly different $(P<0.05)$.

TABLE 3: Effects of preheating $\mathrm{pH}$ and TGase contents on the firmness of acid-induced yak milk gels.

\begin{tabular}{lccr}
\hline & & Firmness $(N)$ & \\
& 0 U/g protein & 3 U/g protein & 10 U/g protein \\
\hline Heating pH 7.1 & $2.9 \pm 0.4^{\mathrm{b}}$ & $4.0 \pm 0.5^{\mathrm{b}}$ & $3.5 \pm 0.4^{\mathrm{a}}$ \\
Heating pH 6.7 & $3.1 \pm 0.6^{\mathrm{b}}$ & $4.5 \pm 0.4^{\mathrm{b}}$ & $3.2 \pm 0.6^{\mathrm{a}}$ \\
Heating pH 6.3 & $2.2 \pm 0.3^{\mathrm{a}}$ & $3.2 \pm 0.4^{\mathrm{a}}$ & $3.6 \pm 0.4^{\mathrm{a}}$ \\
\hline
\end{tabular}

Values are mean \pm standard deviation; means with different superscript letters within the same column are significantly different $(P<0.05)$.

TABLE 4: Effects of preheating pH and TGase contents on the WHC of acid-induced yak milk gels.

\begin{tabular}{lccc}
\hline & & WHC (\%) & \\
& 0 U/g protein & 3 U/g protein & 10 U/g protein \\
\hline Heating pH 7.1 & $80.4 \pm 2.4^{\mathrm{b}}$ & $91.3 \pm 5.1^{\mathrm{b}}$ & $83.7 \pm 6.7^{\mathrm{a}}$ \\
Heating pH 6.7 & $83.4 \pm 3.5^{\mathrm{b}}$ & $93.4 \pm 6.2^{\mathrm{b}}$ & $88.5 \pm 5.1^{\mathrm{a}}$ \\
Heating pH 6.3 & $75.4 \pm 4.7^{\mathrm{a}}$ & $85.5 \pm 4.8^{\mathrm{a}}$ & $85.8 \pm 5.8^{\mathrm{a}}$ \\
\hline
\end{tabular}

Values are mean \pm standard deviation; means with different superscript letters within the same column are significantly different $(P<0.05)$.

method for improving the textural properties of the yogurt gel network, excess crosslinking of caseins in micelles can inhibit the adequate rearrangement of caseins during gelation [22]. This might explain why the samples treated with $3 \mathrm{U}$ TGase per gram proteins were higher than the samples treated with $10 \mathrm{U}$ TGase per gram proteins.

3.3. Water Holding Capacity and Firmness. The firmness of the gels is given in Table 3. For the samples treated with 0 or $3 \mathrm{U}$ TGase per gram proteins, firmness of the final gels was higher at preheating $\mathrm{pH}$ values of 6.7 or 7.1 than at 6.3, whereas no significant difference was observed between $\mathrm{pH}$ 6.7 and 7.1. However, when the samples were treated with $10 \mathrm{U}$ TGase per gram proteins, no significant differences were observed among different preheating $\mathrm{pH}$ values. When the preheating $\mathrm{pH}$ values were definite, the TGase contents also had a significant impact on gel firmness. When the heating $\mathrm{pH}$ was 6.7 , the maximum firmness value was seen in the sample treated with $3 \mathrm{U}$ TGase per gram proteins. Similar results were also observed when the preheating $\mathrm{pH}$ was 7.1. At a definite $\mathrm{pH}$ value, maximum firmness was observed at $3 \mathrm{U}$ TGase per gram proteins.

The WHC of the gels prepared with different preheating $\mathrm{pH}$ and TGase contents is given in Table 4. When the preheating $\mathrm{pH}$ values were definite, the WHC of samples treated with 0 and $10 \mathrm{U}$ TGase per gram proteins showed no significant difference but were lower than the samples treated with $3 \mathrm{U}$ TGase per gram proteins. When the TGase contents were 0 and $3 \mathrm{U}$ TGase per gram proteins, the WHC of the samples treated with preheating $\mathrm{pH} 6.7$ or 7.1 was higher than that with preheating $\mathrm{pH} 6.3$, while the samples treated with pH 6.7 and 7.1 showed no significant difference. For the samples treated with $10 \mathrm{U}$ TGase per gram proteins, the samples with different $\mathrm{pH}$ treatments showed no significant differences.

3.4. Microstructure and Crosslinking Degree. The microstructure of acid-induced yak milk gels prepared from yak skim milk with preheating at $\mathrm{pH} 7.1$ and different TGase contents are shown in Figure 3. In the samples treated with $3 \mathrm{U}$ TGase per gram proteins, more rigid network structures were observed in the gel than 0 or $10 \mathrm{U}$ TGase per gram proteins. This was consistent with the results of the textural properties. The crosslinking degrees of proteins (catalyzed by TGase) in milk samples heated at $\mathrm{pH} 6.3,6.7$, and 7.1 were $15.3 \pm 3.7 \%, 33.2 \pm 5.2 \%$, and $38.1 \pm 4.7 \%$, respectively. This indicated that the number of covalent bonds introduced was positively related to the heating $\mathrm{pH}$ values. As mentioned above, more denatured whey proteins were present in the micellar phase when the heating $\mathrm{pH}$ of yak skim milk was lower, together with the fact that casein cannot be dissociated from the micelles [28]. This indicated that the attached whey proteins with casein micelles might hinder crosslinking between caseins, and thus, the crosslinking sites between proteins are limited. On the contrary, when the heating $\mathrm{pH}$ of yak skim milk was higher, dissociation of micelles may occur, and more sites catalyzed by TGase might be exposed, together with the fact that denatured whey proteins in the soluble phase cannot attach onto the surface of casein micelles which might hinder crosslinking. Therefore, the crosslinking degree of milk proteins (catalyzed by TGase) was higher when the yak skim milk $\mathrm{pH}$ value was high. 


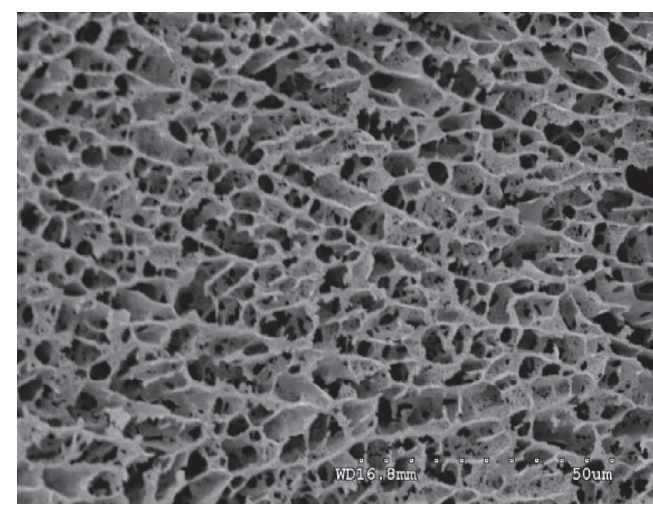

(a)

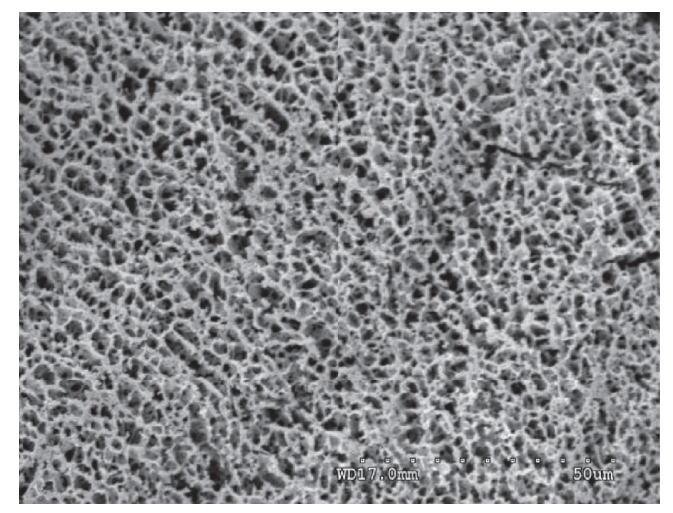

(b)

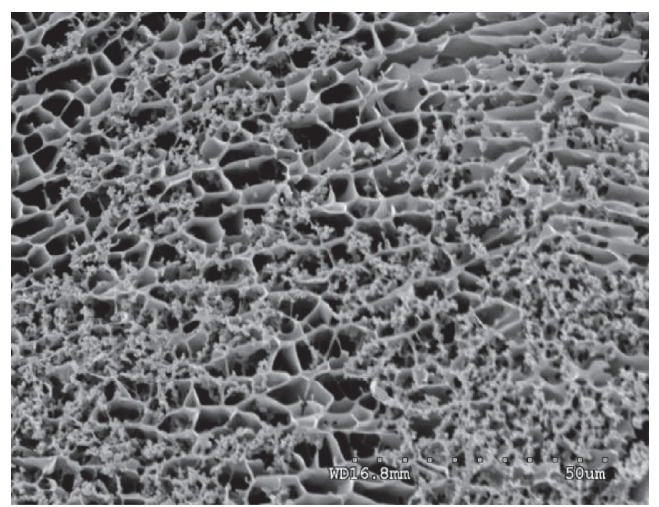

(c)

FIGURE 3: The microstructure of acid-induced yak milk gels prepared from skim yak milk with preheating pH 7.1 and 0 (a), 3 (b), and 10 (c) $\mathrm{U}$ TGase per gram proteins.

\section{Conclusions}

In this study, we investigated the effects of TGase and heat treatment of yak skim milk on the gelation kinetics and texture of acid-induced milk gels, as well as the related mechanism of action. For a given TGase content, the final $\mathrm{G}^{\prime}$ was positively related to the preheating $\mathrm{pH}$ when the preheating $\mathrm{pH}$ increased from 6.3 to 7.1 , whereas the opposite trend was observed for the gelation time. The yak skim milk treated with a preheating $\mathrm{pH}$ value of 7.1 and $3 \mathrm{U}$ TGase per gram proteins demonstrated the highest WHC and firmness and more rigid network structures.

\section{Data Availability}

The data used to support the findings of this study are included within the article.

\section{Conflicts of Interest}

The authors declare that there are no conflicts of interest.

\section{Acknowledgments}

The authors acknowledge the central government for the support in the development of local colleges and Universities in Tibet (503118004), Natural Science Foundation of Tibet Autonomous Region (766660029), Key Laboratory of Food
Science and Engineering, Education Department of Tibet Autonomous Region, and Research and Equipment Development of Free-Range Yak Milk Preservation Technology (2021YFQ0024).

\section{References}

[1] S. R. Barsila, "Effect of parity in different grazing seasons on milk yield and composition of cattle $\times$ yak hybrids in the Himalayan alpines," Journal of Applied Animal Research, vol. 47, no. 1, pp. 591-596, 2019.

[2] H. Zhang, J. Xu, J. Wang et al., "A survey on chemical and microbiological composition of kurut, naturally fermented yak milk from Qinghai in China," Food Control, vol. 19, no. 6, pp. 578-586, 2008.

[3] H. Li, Y. Ma, J. Xiang et al., "Comparison of the immunogenicity of yak milk and cow milk," European Food Research and Technology, vol. 233, no. 4, pp. 545-551, 2011.

[4] X. Ao, X. Zhang, X. Zhang et al., "Identification of lactic acid bacteria in traditional fermented yak milk and evaluation of their application in fermented milk products," Journal of Dairy Science, vol. 95, no. 3, pp. 1073-1084, 2012.

[5] X. Wang, E. Kristo, and G. LaPointe, "Adding apple pomace as a functional ingredient in stirred-type yogurt and yogurt drinks," Food Hydrocolloids, vol. 100, pp. 1-10, 2020.

[6] A. Gilbert, L.-E. Rioux, D. St-Gelais, and S. L. Turgeon, "Studying stirred yogurt microstructure using optical microscopy: how smoothing temperature and storage time affect 
microgel size related to syneresis," Journal of Dairy Science, vol. 103, no. 3, pp. 2139-2152, 2020.

[7] F. Lazzaro, A. Bouchoux, J. Raynes et al., "Tailoring the structure of casein micelles through a multifactorial approach to manipulate rennet coagulation properties," Food Hydrocolloids, vol. 101, Article ID 105414, 2020.

[8] W. J. Lee and J. A. Lucey, "Structure and physical properties of yogurt gels: effect of inoculation rate and incubation temperature," Journal of Dairy Science, vol. 87, no. 10, pp. 3153-3164, 2004.

[9] J. A. Lucey, "Formation and physical properties of milk protein gels," Journal of Dairy Science, vol. 85, no. 2, pp. 281-294, 2002.

[10] Y. Levinson, S. Ish-Shalom, E. Segal, and Y. D. Livney, "Bioavailability, rheology and sensory evaluation of fat-free yogurt enriched with $\mathrm{VD}_{3}$ encapsulated in re-assembled casein micelles," Food \& Function, vol. 7, no. 3, pp. 1477-1482, 2016.

[11] N. A. Bringe and J. E. Kinsella, "Acidic coagulation of casein micelles: mechanisms inferred from spectrophotometric studies," Journal of Dairy Research, vol. 57, no. 3, pp. 365-375, 2009.

[12] A. Körzendörfer, J. Schäfer, J. Hinrichs, and S. Nöbel, "Power ultrasound as a tool to improve the processability of proteinenriched fermented milk gels for Greek yogurt manufacture," Journal of Dairy Science, vol. 102, no. 9, pp. 7826-7837, 2019.

[13] Š. Zamberlin and D. Samaržija, "The effect of non-standard heat treatment of sheep's milk on physico-chemical properties, sensory characteristics, and the bacterial viability of classical and probiotic yogurt," Food Chemistry, vol. 225, pp. 62-68, 2017.

[14] T. Zhang, J. McCarthy, G. Wang, Y. Liu, and M. Guo, "Physiochemical properties, microstructure, and probiotic survivability of nonfat goats' milk yogurt using heat-treated whey protein concentrate as fat replacer," Journal of Food Science, vol. 80, pp. 788-794, 2015.

[15] H. J. Giroux and M. Britten, "Heat treatment of whey proteins in the presence of anionic surfactants," Food Hydrocolloids, vol. 18, no. 4, pp. 685-692, 2004.

[16] J. A. Lucey, M. Tamehana, H. Singh, and P. A. Munro, "Effect of interactions between denatured whey proteins and casein micelles on the formation and rheological properties of acid skim milk gels," Journal of Dairy Research, vol. 65, no. 4, pp. 555-567, 1998.

[17] F. Remeuf, S. Mohammed, I. Sodini, and J. P. Tissier, "Preliminary observations on the effects of milk fortification and heating on microstructure and physical properties of stirred yogurt," International Dairy Journal, vol. 13, no. 9, pp. 773-782, 2003.

[18] S. G. Anema and Y. Li, "Association of denatured whey proteins with casein micelles in heated reconstituted skim milk and its effect on casein micelle size," Journal of Dairy Research, vol. 70, no. 1, pp. 73-83, 2003.

[19] C. M. M. Lakemond and T. Van Vliet, "Acid skim milk gels: the gelation process as affected by preheating $\mathrm{pH}$," International Dairy Journal, vol. 18, no. 5, pp. 574-584, 2008.

[20] P. Wang, H. Liu, P. Wen, H. Zhang, H. Guo, and F. Ren, "The composition, size and hydration of yak casein micelles," International Dairy Journal, vol. 31, no. 2, pp. 107-110, 2013.

[21] M. Jacob, S. Nöbel, D. Jaros, and H. Rohm, "Physical properties of acid milk gels: acidification rate significantly interacts with cross-linking and heat treatment of milk," Food Hydrocolloids, vol. 25, no. 5, pp. 928-934, 2011.

[22] S. G. Anema, S. K. Lee, E. K. Lowe, and H. Klostermeyer, "Rheological properties of acid gels prepared from heated $\mathrm{pH}$ - adjusted skim milk," Journal of Agricultural and Food Chemistry, vol. 52, no. 2, pp. 337-343, 2004.

[23] S. G. Anema and A. B. McKenna, "Reaction kinetics of thermal denaturation of whey proteins in heated reconstituted whole milk," Journal of Agricultural and Food Chemistry, vol. 44, no. 2, pp. 422-428, 1996.

[24] A. Duerasch, J. Wissel, and T. Henle, "Reassembling of alkalitreated casein micelles by microbial transglutaminase," Journal of Agricultural and Food Chemistry, vol. 66, no. 44, pp. 11748-11756, 2018.

[25] B. Noh and T. Richardson, "Incorporation of radiolabeled whey proteins into casein micelles by heat processing," Journal of Dairy Science, vol. 72, no. 7, pp. 1724-1731, 1989.

[26] S. Wu, J. Fitzpatrick, K. Cronin, and S. Miao, "Effects of calcium chelation on the neutralization of milk protein isolate and casein micelle reassembling," Food Chemistry, vol. 332, Article ID 127440, 2020.

[27] H. Li, Y. Ma, A. Dong et al., "Protein composition of yak milk," Dairy Science \& Technology, vol. 90, no. 1, pp. 111-117, 2010.

[28] S. G. Anema and H. Klostermeyer, "Heat-induced, pH-dependent dissociation of casein micelles on heating reconstituted skim milk at temperatures below $100^{\circ} \mathrm{C}$," Journal of Agricultural and Food Chemistry, vol. 45, no. 4, pp. 1108-1115, 1997. 